very much like to know which are the fossils of the strata underlying the Dictyonema Schists to which Mr. Hicks refers as being "Silurian in type and not Cambrian." To me the scanty knowledge of the fauna of these beds does not seem sufficient to warrant, per se, a conclusion as to their age. Fortunately, the sequence of the strata gives a good clue. The Dictyonema Schists of Sweden are very nearly related to the Olenus Schists, which they always immediately overlie, in some places seemingly without any sharp line of demarcation. The Olenus Schists of Sweden are exactly equivalent to the Lingula Flags of England, and therefore the rocks underlying the Russian Dictyonema Schists cannot, at least, be younger than the Lingula Flags, if we are to judge from the palæontological evidences, and from the sequence of the strata.

Mr. Hicks says that if I could only be brought to recognize his views of the gradual encroachment of the sea from a western or south-western direction over the European area, I should certainly feel none of those difficulties which now occur to my mind. It may bo so, but it is my habit, in scientific investigations, first to make myself acquainted with facts, and then to proceed to generalizations. Even if Mr. Hicks may think it more proper and easy first to form theories, and then to "dispose of" the facts, so that they may not interfere with the theories, I cannot help thinking that the opposite way is the true one, and that the knowledge of facts must forego the forming of theories. As I-and probably also your readers-now begin to feel tired of the paper war with Mr. Hicks, I shall not hereafter pursue it.

G. Linnarsson.

SECTION OF BOULDER-CLAY, NORTH DOCKS, LIVERPOOL.

SIr,-As a natural consequence of the two recent letters in the Geological Magazine, in reference to the Boulder-clay recently exposed in the new dock works to the north of Liverpool, I beg to hand you a copy of the Repart I sent, as a member of the Committee, to the Rev. H. W. Crosskey, F.G.S., Secretary of the Boulder Committee of the British Association.

"Recently very extensive excavations have been made in the Boulder-clay at Bootle, a northern suburb of Liverpool. The site is intended for new docks, and extends along the River Mersey, being reclaimed from the shore within the tidal range. The following is a section of the Drift deposits that have been exposed continuously over many acres; but the thickness of each varies considerably according to position, and the Middle Sands and Gravels often thin out and leave the Upper Boulder-clay reposing on the Lower Boulder-clay.

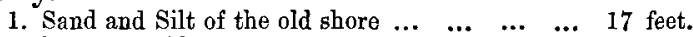

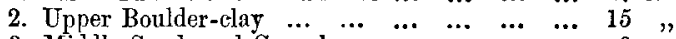

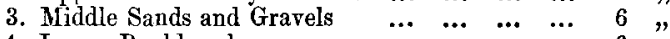

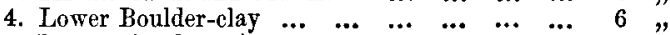
(Bunter Sandstone)

"The whole of these subdivisions repose, each in succession, on the Bunter Sandstone at that part of the section nearest the old coast-line.

"The Lower Boulder-clay contains a much greater quantity of 
small stones than the Upper Clay. No large boulders were observed; but as the Lower Boulder-clay is not exhibited to any considerable depth, it may possibly contain some such boulders.

"The Middle Sands and Gravels consist of sands which frequently by the great increase of rounded pebbles become gravels exactly resembling those at Preston Junction and Wigan in Lancashire, and Gresford, Corwen, and Colwyn in North Wales.

"The Upper Boulder-clay contains comparatively few small stones, but many large boulders, two or three feet in diameter. Many of these are striated, and are composed of a dark greenstone; but some are Criffel and Eskdale granite. These large boulders probably occur at an average distance of twenty yards from each other. A mass of compact gypsum about $4 \mathrm{ft}$. in diameter was also observed.

"The excavators al ways worked the Upper Clay with a spade, and the Lower Clay with a pick, in consequence of which the difference between the two clays could be distinguished at a considerable distance, whether the Middle Sands and Gravels were between them or not."

I may now add that for many months during the progress of the excavation the section was of the clearest possible character. Over an area of many acres, the Upper Boulder-clay had been removed, as well as the underlying Sands and Gravels, leaving the Lower Boulder-clay untouched except where it rose above the genera] level intended for the bottom of the Docks. In such instances it was directly covered with the Upper Boulder-clay-though the line of separation was invariably clear and distinct. The Middle Sands and Gravels varied continuously, from fine and coarse sand into gravel and pebble beds; and indicate very different conditions of deposition compared to that of the two Boulder-clays. In conclusion I need only remark that this tripartite division of Glacial deposits at Liverpool strengthens similar conclusions in North Wales and Lancashire, and proves their general application over a wide area.

122, LoNdon ROAD, LIVERPOOL.

GEORGE H. MoRton.

\section{THE GRAPTOLITIC MUDSTONES OF THE LAKE DISTRICT.}

Sir,-Mr. C. Lapworth's argument in favour of the Graptolitic Mudstones of the Lake district being Lower Llandovery would be very strong if there was a physical break between them and the overlying formations, but this is not the case. The Mudstones graduate upwards into the pale and purple-coloured slates, which in their turn graduate upwards into the Coniston Flags, and so upwards into the Bannerdale beds. From the base of the Mudstones to the top of the Bannerdales is one conformable series. The disappearance of the Graptolites of the Mudstones is not sudden, they are found in the dark bands interstratified with the pale slates to the very top.

I do not believe there can be an enormous break indicating a long lapse of time without there being some signs of unconformity or overlap; in this case there is none, not even a sharp junction.

KENDAL, 20th Oct., 1876.

W. Talbot Aveline. 